\title{
Antiprotozoal and molluscicidal activities of five Brazilian plants
}

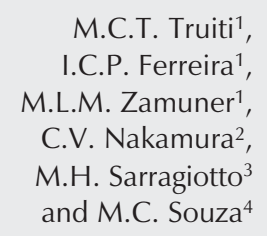

\author{
${ }^{1}$ Departamento de Farmácia e Farmacologia, ${ }^{2}$ Departamento de Análises Clínicas, \\ Centro de Ciências da Saúde, ${ }^{3}$ Departamento de Química, Centro de Ciências Exatas, \\ ${ }^{4}$ Departamento de Biologia, Centro de Ciências Biológicas, \\ Universidade Estadual de Maringá, Maringá, PR, Brasil
}

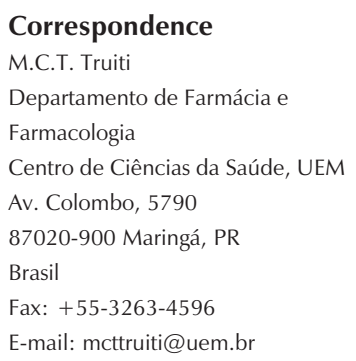

Received December 17, 2004 Accepted August 9, 2005

\section{Abstract}

Leishmaniasis, Chagas' disease and schistosomiasis (bilharzia) are parasitic diseases with wide distribution on the American continent, affecting millions of people. In the present study, biological assays for antiprotozoal and molluscicidal activities were carried out with ethanolic extracts of plant species from the Brazilian part of the Upper Paraná River. Crude extracts were obtained by percolation with absolute ethanol from the leaves of Cayaponia podantha Cogn., Nectandra falcifolia (Nees) Castiglioni and Paullinia elegans Cambess., as well as from the aerial parts of Helicteres gardneriana St. Hil. \& Naud. and Melochia arenosa Benth., all belonging to genera used in folk medicine. Trypanocidal activity of plants was assayed on epimastigote cultures in liver infusion tryptose. Anti-leishmanial activity was determined over cultures of promastigote forms of the parasite in Schneider's Drosophila medium. Microscopic countings of parasites, after their incubation in the presence of different concentrations of the crude extracts, were made in order to determine the percentage of growth inhibition. C. podantha and M. arenosa, at a concentration of $10 \mu \mathrm{g} / \mathrm{mL}$, showed $90.4 \pm 11.52$ and $88.9 \pm 2.20 \%$ growth inhibition, respectively, of epimastigote forms of Trypanosoma cruzi, whereas $N$. falcifolia demonstrated an $\mathrm{LD}_{50}$ of $138.5 \mu \mathrm{g} / \mathrm{mL}$ against promastigote forms of Leishmania (Viannia) braziliensis. Regarding molluscicidal activity, the acute toxicity of the extracts on Biomphalaria glabrata was evaluated by a rapid screening procedure. M. arenosa was $100 \%$ lethal to snails at $200 \mu \mathrm{g} / \mathrm{mL}$ and showed an $\mathrm{LD}_{50}$ of $143 \mu \mathrm{g} / \mathrm{mL}$. Screening of plant extracts represents a continuous effort to find new antiparasitic drugs.

\section{Introduction}

The general floristic research on diversity in the Upper Paraná River floodplain, area of Porto Rico (PR, Brazil), carried out by Souza et al. (1), demonstrated high floristic heterogeneity characterized by forest for-

\section{Key words}

- Cayaponia podantha

- Helicteres gardneriana

- Melochia arenosa

- Nectandra falcifolia

- Paullinia elegans

- Antiprotozoal activity

- Molluscicidal activity .................... 
the authors registered 117 families and 652 species. Many of these plants are used in folk medicine, and most of them have not been studied scientifically.

In the last few years, much research has been carried out to evaluate the effectiveness and safety of the use of plants or their metabolites for the prevention or treatment of diseases. Screening of plant extracts represents a continuous effort to find new bioactive molecules or extracts. Approximately $20 \%$ of the plants in the world or their extracts have been submitted to pharmacological or biological tests (2).

American tegumentary leishmaniasis, Chagas' disease and schistosomiasis (bilharzia) are parasitic diseases with wide distribution on the American continent, affecting millions of people, primarily those with the worst living conditions (3). Plants with antiprotozoal or molluscicidal activities can be useful tools to control these diseases.

American tegumentary leishmaniasis, whose etiological agents are flagellate protozoa of the genus Leishmania (family Trypanosomatidae), affects skin and mucous membranes and can cause disfiguring lesions (4). The etiological agent of Chagas' disease is Trypanosoma cruzi, also a flagellate protozoan belonging to the family Trypanosomatidae. This parasitic disease may cause mainly cardiomyopathy and megasyndromes (3). Clinical data demonstrate that the current drugs for the treatment of these diseases present several side effects and do not always provide the desired cure levels (3,5-7).

Schistosomiasis is an important endemic disease in Brazil. Its etiological agent, the helminth Schistosoma mansoni (family Schistosomatidae), requires snails of stagnant or slow-flowing fresh water to complete its developmental cycle, with the species Biomphalaria glabrata (family Planorbidae) being the most important vector of $S$. mansoni in Brazil. The severity of the clinical forms causes much concern and can lead to death (3). The synthetic molluscicides that have been used are very expensive, can be toxic to other organisms, and can lead to deleterious long-term effects on the environment and to the development of resistance by vector snails $(8,9)$. Thus, other alternatives need to be evaluated.

In the present study, we evaluated the antiprotozoal and molluscicidal activities of the plant species Cayaponia podantha Cogn. (Cucurbitaceae) popularly known as "taiuiá", Helicteres gardneriana St. Hil. \& Naud. (Sterculiaceae) "sacarrolha", Melochia arenosa Benth. (Sterculiaceae) "malva", Nectandra falcifolia (Nees) Castiglioni (Lauraceae) "canelinha" and Paullinia elegans Cambess. (Sapindaceae) "cipó-timbó".

\section{Material and Methods}

\section{Plant material}

Vegetative samples of the five species were collected from riparian vegetation on banks in different areas of the Upper Paraná River floodplain: $C$. podantha (leaves) and $H$. gardneriana (aerial parts) from the Ivinhema River, municipal district of Jatei (MS, Brazil), M. arenosa (aerial parts) from Garças' Lake, municipal district of Bataiporã (MS, Brazil), N. falcifolia (leaves) from the Baía River, municipal district of Taquaruçu (MS, Brazil), and P. elegans (leaves) from Figueira's Pond, municipal district of Porto Rico (PR, Brazil). Voucher specimens of each species were added to the collection of the HNUP Herbarium (Nupelia, Universidade Estadual de Maringá, PR, Brazil; Registration Numbers 1281, 2844, 1834, 1421, and 463 , respectively).

\section{Extraction}

The following amounts of dried plant parts were powdered with a knife mill: $200 \mathrm{~g}$ C. podantha, $450 \mathrm{~g} \mathrm{H}$. gardneriana, $600 \mathrm{~g}$ M. arenosa, $580 \mathrm{~g} \mathrm{~N}$. falcifolia, and $395 \mathrm{~g} P$. 
elegans. Crude extracts were obtained by extraction with absolute ethanol at room temperature, and the solvent was removed by rotary evaporation under reduced pressure, producing $15.8,32.7,71.0,64.0$, and $55.8 \mathrm{~g}$ of ethanolic extracts, respectively.

\section{Culture and maintenance of the parasites}

Leishmania (Viannia) braziliensis promastigotes, strain MHOM/BR1987/M11272, were grown at $25^{\circ} \mathrm{C}$ in Schneider's Drosophila medium supplemented with $10 \%$ (v/v) heat-inactivated fetal calf serum. Cells were harvested in the late log phase (day 3 of culture), resuspended in fresh medium, counted in a Neubauer chamber and adjusted to a concentration of $4 \times 10^{6}$ promastigotes/mL. T. cruzi epimastigotes, strain Y, were cultivated in liver infusion tryptose medium (10) containing $10 \%$ fetal calf serum and incubated at $28^{\circ} \mathrm{C}$ for $96 \mathrm{~h}$. Both parasite strains were maintained through weekly transfers in the respective medium.

\section{Anti-leishmanial activity}

The assay was conducted as described by Araujo et al. (5) and Ferreira et al. (11). Growth inhibition of $L$. (V.) braziliensis promastigotes was evaluated with the ethanolic extract of the plants at concentrations ranging from 0.125 to $320 \mu \mathrm{g} / \mathrm{mL}$. The extracts were dissolved in DMSO (the highest concentration used was $1.6 \%, \mathrm{v} / \mathrm{v}$ ) added to the promastigote cultures (day 3 of culture) at 4 x $10^{6}$ promastigotes $/ \mathrm{mL}$, and incubated at $25^{\circ} \mathrm{C}$. After $24 \mathrm{~h}$, the surviving parasites were counted in a Neubauer chamber and their number was compared with that of controls grown in the presence of DMSO only. All tests were done in triplicate and pentamidine isethionate $(0.7 \mu \mathrm{g} / \mathrm{mL}$; May \& Baker Lab., London, UK) was used as reference drug. The $\mathrm{LD}_{50} / 24 \mathrm{~h}$ values were determined by linear regression analysis using statistical error limits up to $10 \%$.

\section{Anti-Trypanosoma cruzi activity}

The growth inhibition of $T$. cruzi epimastigotes was evaluated with the ethanolic extract of the plants $(10,100$, or $1000 \mu \mathrm{g} / \mathrm{mL})$. The extracts were dissolved in DMSO, added to the culture medium and the parasites $(1 \mathrm{x}$ $10^{6}$ epimastigotes $/ \mathrm{mL}$ ) were cultivated for $96 \mathrm{~h}$ at $28^{\circ} \mathrm{C}$. Growth was evaluated by counting in a Neubauer chamber and compared to that of controls grown in medium containing only DMSO (1.0\%). All tests were done in duplicate and benznidazole (10 $\mu \mathrm{g} / \mathrm{mL}$; N-benzyl-2-nitro-1-imidazolacetamide; Roche Pharmaceuticals, Rio de Janeiro, RJ, Brazil) was used as reference drug.

\section{Maintenance of the snails}

The snails, B. glabrata, SUCEN strain, were maintained in aquaria with potable water, air circulation, aquatic plants, and Poecilia reticulata fishes, at room temperature. Mature snails, relatively uniform in age and size (shell diameter: 10-12 $\mathrm{mm}$ ), were used for the tests.

\section{Molluscicidal activity}

The acute toxicity on $B$. glabrata was evaluated by a rapid screening procedure $(9,12)$. The ethanolic extracts were dissolved in $100 \mu \mathrm{l}$ DMSO at the concentration of 400 , 300 , or $200 \mu \mathrm{g} / \mathrm{mL}$ and then added to glass beakers containing $100 \mathrm{~mL}$ of water from the aquaria. Two snails were placed in each container and maintained in a well-aerated place at room temperature. After $24 \mathrm{~h}$ the snails were placed on a Petri dish and their heartbeats were checked using a stereomicroscope. For all extracts that were $100 \%$ lethal at the concentration of $200 \mu \mathrm{g} / \mathrm{mL}$, the concentrations of 150,100 , and $50 \mu \mathrm{g} / \mathrm{mL}$ were also tested. For these assays, ten snails were used, with a $50-\mathrm{mL}$ volume of aquarium water per snail. To confirm mortality the snails were transferred to vessels containing 
only distilled water and their condition was re-evaluated $24 \mathrm{~h}$ later. A control was carried out with DMSO. All tests were performed in duplicate and niclosamide $(5 \mu \mathrm{g} /$ $\mathrm{mL}$; Bayluscide ${ }^{\circledR}$, Bayer AG, Leverkusen, Germany) was used as reference drug.

Table 1. Effect of ethanolic extracts of Cayaponia podantha (Cp), Helicteres gardneriana $(\mathrm{Hg})$, Melochia arenosa $(\mathrm{Ma})$, Nectandra falcifolia (Nf), and Paullinia elegans $(\mathrm{Pe})$ on the growth of Leishmania (Viannia) braziliensis promastigotes.

\begin{tabular}{lcccc}
\hline Plant & \multicolumn{4}{c}{$\%$ Growth inhibition } \\
\cline { 2 - 5 } & $40 \mu \mathrm{g} / \mathrm{mL}$ & $80 \mu \mathrm{g} / \mathrm{mL}$ & $160 \mu \mathrm{g} / \mathrm{mL}$ & $320 \mu \mathrm{g} / \mathrm{mL}$ \\
\hline $\mathrm{Cp}$ & $\mathrm{NI}$ & $\mathrm{NI}$ & $38.6 \pm 8.2$ & $55.3 \pm 5.2$ \\
$\mathrm{Hg}$ & $\mathrm{NI}$ & $\mathrm{NI}$ & $44.0 \pm 9.8$ & $56.0 \pm 9.0$ \\
$\mathrm{Ma}$ & $\mathrm{NI}$ & $\mathrm{NI}$ & $\mathrm{NI}$ & $45.2 \pm 3.3$ \\
$\mathrm{Nf}$ & $\mathrm{NI}$ & $25.0 \pm 9.4$ & $59.4 \pm 5.4$ & $65.6 \pm 5.4$ \\
$\mathrm{Pe}$ & $\mathrm{NI}$ & $5.5 \pm 0.0$ & $11.2 \pm 1.9$ & $12.3 \pm 3.4$ \\
\hline
\end{tabular}

$\mathrm{NI}=$ not inhibited

Table 2. Effect of ethanolic extrats of Cayaponia podantha (Cp), Helicteres gardneriana $(\mathrm{Hg})$, Melochia arenosa (Ma), Nectandra falcifolia (Nf), and Paullinia elegans (Pe) on the growth of Trypanosoma cruzi epimastigotes.

\begin{tabular}{llll}
\hline Plant & \multicolumn{3}{c}{$\%$ Growth inhibition } \\
\cline { 2 - 4 } & $10 \mu \mathrm{g} / \mathrm{mL}$ & $100 \mu \mathrm{g} / \mathrm{mL}$ & $1000 \mu \mathrm{g} / \mathrm{mL}$ \\
\hline $\mathrm{Cp}$ & $90.4 \pm 11.52$ & $89.4 \pm 12.30$ & $95.0 \pm 0.92$ \\
$\mathrm{Hg}$ & $65.3 \pm 11.53$ & $79.7 \pm 10.89$ & $85.5 \pm 16.19$ \\
$\mathrm{Ma}$ & $88.9 \pm 2.20$ & $94.0 \pm 0.49$ & $98.7 \pm 0.21$ \\
$\mathrm{Nf}$ & $73.8 \pm 7.19$ & $79.7 \pm 1.61$ & $94.0 \pm 3.58$ \\
$\mathrm{Pe}$ & $79.6 \pm 0.85$ & $90.5 \pm 2.19$ & $96.5 \pm 2.12$ \\
\hline
\end{tabular}

Table 3. Molluscicidal activity of ethanolic extracts of Cayaponia podantha (Cp), Helicteres gardneriana $(\mathrm{Hg})$, Melochia arenosa (Ma), Nectandra falcifolia (Nf), and Paullinia elegans $(\mathrm{Pe})$ against Biomphalaria glabrata.

\begin{tabular}{lcccccc}
\hline Plant & \multicolumn{6}{c}{$\%$ Mortality } \\
\cline { 2 - 7 } & $50 \mu \mathrm{g} / \mathrm{mL}$ & $100 \mu \mathrm{g} / \mathrm{mL}$ & $150 \mu \mathrm{g} / \mathrm{mL}$ & $200 \mu \mathrm{g} / \mathrm{mL}$ & $300 \mu \mathrm{g} / \mathrm{mL}$ & $400 \mu \mathrm{g} / \mathrm{mL}$ \\
\hline $\mathrm{Cp}$ & $\mathrm{ND}$ & $\mathrm{ND}$ & $\mathrm{ND}$ & - & - & - \\
$\mathrm{Hg}$ & $\mathrm{ND}$ & $\mathrm{ND}$ & ND & - & - & - \\
$\mathrm{Ma}$ & - & 10 & 60 & 100 & 100 & 100 \\
$\mathrm{Nf}$ & - & - & - & 100 & 100 & 100 \\
$\mathrm{Pe}$ & $\mathrm{ND}$ & ND & ND & - & - & - \\
\hline
\end{tabular}

- = inactive; ND = not determined.

\section{Results and Discussion}

Several natural compounds have been identified for the treatment of leishmaniasis and research on plants and their metabolites can contribute to overcoming the drug resistance of Leishmania parasites (7). Among the plant species evaluated here, $N$. falcifolia presented the best results regarding antileishmanial activity, with the ethanolic leaf extract displaying an $\mathrm{LD}_{50}$ of $138.5 \mu \mathrm{g} / \mathrm{mL}$ and $65.6 \pm 5.4 \%$ growth inhibition of the promastigote forms of $L$. (V.) braziliensis at the highest concentration tested, $320 \mu \mathrm{g} / \mathrm{mL}$ (Table 1). Extracts of $H$. gardneriana (aerial parts) and $C$. podantha (leaves), which also demonstrated reasonable potency, presented an $\mathrm{LD}_{50}$ of 237 and $271 \mu \mathrm{g} / \mathrm{mL}$, respectively. No growth inhibition was obtained at drug concentrations lower that $40 \mu \mathrm{g} / \mathrm{mL}$. The medium containing DMSO did not affect the growth of the protozoa.

Ethanolic extracts of $C$. podantha and $M$. arenosa (aerial parts) inhibited the growth of epimastigote forms of $T$. cruzi even at very low concentrations $(10 \mu \mathrm{g} / \mathrm{mL})$, presenting $90.4 \pm 11.52$ and $88.9 \pm 2.20 \%$ growth inhibition of this protozoan, respectively. On the other hand, extracts of $H$. gardneriana, $N$. falcifolia, and P. elegans (leaves) showed similar activities only when a concentration of $1000 \mu \mathrm{g} / \mathrm{mL}$ was used (Table 2). The medium containing $1.0 \%$ DMSO did not affect the growth of the protozoa. Benznidazole, used as the positive control against $T$. cruzi at $10 \mu \mathrm{g} / \mathrm{mL}$, showed $80 \%$ growth inhibition (data not shown).

The best results in terms of molluscicidal activity (Table 3) were obtained with the ethanolic extract of $M$. arenosa, which induced 100 and $60 \%$ snail mortality at concentrations of 200 and $150 \mu \mathrm{g} / \mathrm{mL}$, respectively, with an $\mathrm{LD}_{50}$ of $143 \mu \mathrm{g} / \mathrm{mL}$. The $N$. falcifolia extract was $100 \%$ lethal to the snails at the concentration of $200 \mu \mathrm{g} / \mathrm{mL}$, but mortality was not obtained at lower concentrations. Control assays with DMSO showed 
no effect on the snails. Niclosamide at $5 \mu \mathrm{g} /$ $\mathrm{mL}$ was used as positive control against $B$. glabrata and showed $100 \%$ lethality (data not shown).

Although the literature indicates that ideal concentrations of plant extracts are below $100 \mu \mathrm{g} / \mathrm{mL}$ for molluscicidal activity (8), the results obtained for M. arenosa, $\mathrm{LD}_{50}$ of 143 $\mu \mathrm{g} / \mathrm{mL}$, justify the continuation of its study. This plant is native to the area and the extract was obtained from regenerating parts of the plant, factors that can be considered of importance.

The genus Nectandra is well represented in the Brazilian flora, with several species presenting many benefits to man. They have been used in popular medicine for the relief of pain, arthritis, rheumatism and diarrhea, and also as antifungals. Pharmacological studies have demonstrated the antitumoral activity of $N$. rigida Nees, the antimalarial activity of $N$. cuspidata Nees and the vascular and antimalarial activities of $N$. salicifolia Nees (13-17). In our study, N. falcifolia leaves presented good results regarding their antiprotozoal activity against promastigote forms of $L$. (V.) braziliensis.

Some species of the genus Helicteres have been used in folk medicine, such as $H$. isora L. (as an expectorant, demulcent, astringent, antigalactagogue, and for the relief of the flu, against empyema, stomach affections, and diabetes), H. angustifolia (analgesic, anti-inflammatory and anti-bacterial effects), H. ovata Lam. (depurative, emollient and antisyphilitic effects), and $\mathrm{H}$. sacarolha Juss. (depurative and in syphilitic inflammations). Pharmacological studies have demonstrated the antidiabetic and hypolipidemic activities of $H$. isora L. (14,18-20). In our study $H$. gardneriana (aerial parts) also displayed good antiprotozoal activity against promastigote forms of $L$. (V.) braziliensis.

Among the species of the genus Cayaponia that have been used popularly, we may mention $C$. tayuya (Vell.) Cogn. and $C$. espelina Cogn. (anti-snake venom, tonic, diuretic, anti-asthmatic, antisyphilitic, and purgative effects, and to combat epilepsy, diarrhea and bronchitis), C. cabocla M. (purgative and depurative effects in cutaneous diseases and as an emmenagogue) and $C$. pilosa Cogn. (emmenagogue, antisyphilitic and purgative effects) $(14,21)$. Our data demonstrated that $C$. podantha (leaves) presents important antiprotozoal activity against epimastigote forms of $T$. cruzi and promastigote forms of $L$. (V.) braziliensis.

Some species of the genus Melochia have been used in folk medicine, such as $M$. corchorifolia L. (dysentery, abdominal swellings and water-snake bites), M. umbellata (Houtt.) Stapf (deobstruent) and M. pyramidata L. (bronchitis and cough) $(14,22,23)$. The extract obtained from the aerial parts of $M$. arenosa demonstrated molluscicidal effects and activity against $T$. cruzi epimastigotes that can be explored in the future.

Continuous research for new drugs with high activity and reduced adverse effects is very important, especially considering that in Brazil parasitic diseases constitute a serious public health problem. Screening the biodiversity of the tropical forests can reveal new phytotherapeutic drugs, but studies of this type are just beginning. The biodiversity existing in the Brazilian flora is a potential source of many new bioactive molecules (7). The biological properties of the five plant species studied here, $C$. podantha, $H$. gardneriana, $M$. arenosa, $N$. falcifolia, and $M$. arenosa had not been evaluated until the present study. The results obtained here in biological assays with these plant species that occur naturally in the studied area demonstrate that the local flora presents a great medicinal potential. The more active plant extracts were prioritized for fractionation and identification of their active components, a work that is already under way.

\section{Acknowledgments}

We are grateful to Dr. Carmen L. Cristóbal 
and Dr. Maria Silvia Feruci, Instituto de Botanica del Nordeste, Corrientes, Argentina, and to Dr. João Batista Baitelo, Insti- tuto Florestal, São Paulo, SP, Brasil, for identifying the plants.

\section{References}

1. Souza MC, Kita KK, Romagnolo MB et al. (2004). Riparian vegetation of the upper Paraná River floodplain, Paraná and Mato Grosso do Sul States, Brazil. In: Agostinho AA, Rodrigues L, Gomes LC et al. (Editors), Structure and Functioning of the Paraná River and its Floodplain. LTER-site 6 (PELD sítio6). EDUEM, Maringá, PR, Brazil.

2. Suffredini IB, Sader HS, Gonçalves AG et al. (2004). Screening of antibacterial extracts from plants native to the Brazilian Amazon Rain Forest and Atlantic Forest. Brazilian Journal of Medical and Biological Research, 37: 379-384.

3. Funasa (1998). Guia de Vigilância Epidemiológica. Ministério da Saúde, Brasília, DF, Brazil.

4. Silveira TGV, Arraes SMAA, Bertolini DA et al. (1999). Observações sobre o diagnóstico laboratorial e a epidemiologia da leishmaniose tegumentar no estado do Paraná, sul do Brasil. Revista da Sociedade Brasileira de Medicina Tropical, 32: 413-423.

5. Araujo CAC, Alegrio LV \& Leon LL (1998). Antileishmanial activity of compounds extracted and characterized from Centrolobium sclerophyllum. Phytochemistry, 49: 751-754.

6. Rassi A, Neto VA, Siqueira AF et al. (2002). Tratamento da fase crônica da doença de Chagas com nifurtimox associado a corticóide. Revista da Sociedade Brasileira de Medicina Tropical, 35: 547-550.

7. Napolitano HB, Silva M, Ellena J et al. (2004). Aurapten, a coumarin with growth inhibition against Leishmania major promastigotes. Brazilian Journal of Medical and Biological Research, 37: 1847-1852.

8. Marston A \& Hostettmann K (1985). Plant molluscicides. Phytochemistry, 24: 639-652.

9. Bilia AR, Braca A, Mendez J et al. (2000). Molluscicidal and piscicidal activities of Venezuelan Chrysobalanaceae plants. Life Sciences, 66: PL53-PL59.

10. Camargo EP (1964). Growth and differentiation in Trypanosoma cruzi. Origin of metacyclic trypanosomes in liquid media. Revista do Instituto de Medicina Tropical de São Paulo, 6: 93-100.

11. Ferreira ICP, Lonardoni MVC, Machado GMC et al. (2004). Antileishmanial activity of extract from Aspidosperma ramiflorum. Memórias do Instituto Oswaldo Cruz, 99: 325-327.
12. Hostettmann K, Kizu H \& Tomimori T (1982). Molluscicidal properties of various saponins. Planta Medica, 44: 34-35.

13. Le Quesne PW, Larrahondo JE \& Raffauf RF (1980). Antitumor plants. X. Constituents of Nectandra rigida. Journal of Natural Products, 43: 353-359.

14. Correa MP (1984). Dicionário das Plantas Úteis do Brasil e das Exóticas Cultivadas. Instituto Brasileiro de Desenvolvimento Florestal, Rio de Janeiro, RJ, Brazil.

15. Böhlke M, Guinaudeau H, Angerhofer CK et al. (1996). Costaricine, a new antiplasmodial bisbenzylisoquinoline alkaloid from Nectandra salicifolia trunk bark. Journal of Natural Products, 59: 576-580.

16. Slish DF, Ueda H, Arvigo R et al. (1999). Ethnobotany in the search for vasoactive herbal medicines. Journal of Ethnopharmacology, 66: 159-165.

17. Muñoz V, Sauvain M, Bourdy G et al. (2000). A search for natural bioactive compounds in Bolivia through a multidisciplinary approach. Part I. Evaluation of the antimalarial activity of plants used by the Chacobo Indians. Journal of Ethnopharmacology, 69: 127-137.

18. Venkatesh S, Reddy GD, Reddy YSR et al. (2004). Effect of Helicteres isora root extracts on glucose tolerance in glucose-induced hyperglycemic rats. Fitoterapia, 75: 364-367.

19. Chakrabarti R, Vikramadithyan RK, Mullangi R et al. (2002). Antidiabetic and hypolipidemic activity of Helicteres isora in animal models. Journal of Ethnopharmacology, 81: 343-349.

20. Chang YS, Ku YR, Lin JH et al. (2001). Analysis of three lupine type triterpenoids in Helicteres angustifolia by high-performance liquid chromatography. Journal of Pharmaceutical and Biomedical Analysis, 26: 849-855.

21. Lorenzi H (2002). Plantas Medicinais no Brasil: Nativas e Exóticas Cultivadas. Instituto Plantarum, Nova Odessa, SP, Brazil.

22. Bhakuni RS, Shukla YN \& Thakur RS (1987). Chemical constituents of Melochia corchorifolia Linn. Indian Journal of Chemistry, 26B: 1161-1164.

23. Lorenzi H (1991). Plantas Daninhas do Brasil: Terrestres, Aquáticas, Parasitas, Tóxicas e Medicinais. Instituto Plantarum, Nova Odessa, SP, Brazil. 